\begin{tabular}{l|c|c|}
\hline & International Journal of Current Research in \\
Biosciences and Plant Biology \\
EXCELLENT \\
PUBLISHERS
\end{tabular}

Case Report

doi: https://doi.org/10.20546/ijcrbp.2018.505.009

\title{
Safe Use of Highly Inflammable Dry Chirpine (Pinus roxburghii) Needles: A Successful Case Study from Pithoragarh District of Uttarakhand, India
}

\author{
Arvind Bijalwan* \\ Faculty of Technical Forestry, Indian Institute of Forest Management (IIFM), Bhopal, MP, India \\ ${ }^{*}$ Corresponding author.
}

\begin{tabular}{|c|c|}
\hline Article Info & ABSTRACT \\
\hline $\begin{array}{l}\text { Date of Acceptance: } \\
21 \text { April } 2018\end{array}$ & \multirow{4}{*}{$\begin{array}{l}\text { The presence of highly inflammable dry needles of chirpine (Pinus roxburghii) on the } \\
\text { forest floor creates fire hazard in the forests of Uttarakhand Himalaya of India which } \\
\text { is a big concern to the entire state. Safe use of chirpine is a challenge in the state of } \\
\text { Uttarakhand to protect the forest and precious flora and fauna from forest fire. The } \\
\text { successful model in generating electricity using dry needles of chirpine by a company } \\
\text { "Avani Bio Energy" in Chachret village of Pithoragarh district of Uttarakhand, India } \\
\text { has created an eco-friendly example in the state in recent past. }\end{array}$} \\
\hline $\begin{array}{l}\text { Date of Publication: } \\
06 \text { May } 2018\end{array}$ & \\
\hline Keywords & \\
\hline $\begin{array}{l}\text { Avani Bio Energy } \\
\text { Bio-briquettes } \\
\text { Chirpine (Pinus roxburghii) } \\
\text { Chirpine forest } \\
\text { Forest fire }\end{array}$ & \\
\hline
\end{tabular}

\section{Introduction}

Chirpine, scientifically known as Pinus roxburghii, is a conifer that covers about 16 per cent of the forest area in Uttarakhand only. Chirpine occurs in abundance in the outer hills from $600 \mathrm{~m}$ to about $1800 \mathrm{~m}$ altitude; however, chirpine trees grow below $900 \mathrm{~m}$ altitude are generally stunted and crooked. Chirpine needles are highly inflammable and are considered main casual agent of forest fire in this region. The species itself is highly resistant to fire due to thick bark but its exposed resin ducts make it prone to fire.

Earlier people use to either burn these pine needles regularly in the forest itself to clear the forest path, to reduce fuel material for massive fire hazard and to promote the growth of forage grasses and herbaceous plants. But now in the recent years, there is mass migration of people from this hilly district in search for more lucrative jobs and thus, leaving very few families in the villages to maintain 
the forest. There was a time when villagers used to collect the litter (particularly chirpine needles) for the bedding purpose for their domestic animals. Most of chirpine areas near the Oak forest are in difficult hilly terrain and even inaccessible to the forest department thus, requires the help of local people to reach there, but now it has become no man's land in which chirpine is spreading and flourishing and hence, diminishing the forest through fire.

\section{Successful case study of Avani Bio Energy}

The chirpine needles are highly inflammable and are considered good for energy generation. Avani (http://avani-kumaon.org/) was founded in 1999 and works with developing and disseminating appropriate technology and livelihood opportunities in the Himalayan region. In order to scale energy from pine needles, founders of Avani later started a company Avani Bio Energy, under it and started to generated electricity from pine needles from 2013 in Chachret village of Pithoragarh district of Uttarakhand, India. I have telephonically asked the details of Co-Founder of Avani Bio Energy Mr. Rajnish Jain and board member of Avani, Rajendra Kumar Joshi about the successful model of generating electricity through dry chirpine needle. Initially they started with 120-kilowatt power plant, but in initial stage, they could not get the sufficient pine needles to generate the electricity because time period for pine needle collection from forest floor coincides with the farmers getting busy in their agriculture field. Therefore, gradually they reduced the capacity of plant and shifted to 10kilowatt power plant, and replicated it elsewhere too. It is a good example of community management when people collectively providing the pine needle to us or through van panchayat and local people earning money from this. Now they are also starting to set a plant in Almora district of Uttarakhand too. Now, they are going to establish two adequate size power plants of 28-kilowatt. When I asked him whether chirpine needles have good property for energy production, he said that, "because of its good fuel and energy properties the drastic and disastrous forest fire occurs in the chirpine forest". He said "pine needle has excellent energy generation property".

As per Mr. Jain, "in the initial stage when we calculated the economics of energy generation through pine needle and its cost was around Rs. 4.5 to 5.00 per kilowatt but in large scale gradually the input cost will decline". He said, "they are the pioneer in developing this bio-energy development model from pine needles, own the Intellectual Property Right (IPR) and have the patent is in process on it however, some technical support they are outsourcing". With respect to encroachment of pine to the valuable species oak, Mr. Rajnish Jain said, "yes, this species is encroaching oak forest but removing chirpine does not seem to be the solution, as removal will completely deforest the area". Mr. Jain is keenly interested in developing local employment through this way in one hand and reduces the chances of forest fire on other, leading to regeneration of biodiversity. He added that, "if we really want to run the plant successfully, we need as many pine needle collectors as possible". Mr. Jain said, "our pine needle generation plant is popular and has world wide application particularly forest fire prone areas". When I asked to Mr. Rajendra Kumar Joshi, he said "we are collecting the chirpine needles with the help of local people from the chirpine forest and purchasing it @ Rs $2 / \mathrm{kg}$, the local people are happy but they are also busy with their agricultural works". Mr. Joshi said that some van panchayats are also collecting pine needle and providing to us for energy generation. They are also developing charcoal from the chirpine and, it is one of the good species to develop the charcoal.

Thus as per the above successful model, governments of the chirpine states should replicate such models, which will be win-win situation for all. The pine dominant states in India have no pine harvesting and logging policy in place as yet, especially above 1000meter elevation. Recently government of Uttarakhand has come up with a policy "Energy development from chirpine needles and Biomass-2018" for generation of energy using dry chirpine needles and biomass. 
The forest department in the state is imparting training on bio-briquettes making through chirpine needle, but the impact is very poor on local communities and villagers. Many institutes are also providing training on chirpine briquettes making as Rural Technology Centre of G. B. Pant Institute of Himalayan Environment and Development, Almora but the impact on local community is still deficient.

Chirpine needles can be used for making pulp and paper, in fact we have heard the stories of paper making through chirpine needles during olden days in Uttarakhand by some indigenous methods. In a study conducted by Kala and Subbarao the gross annual pine needle yield in Uttarakhand has been estimated as 1.97 million tonnes while the estimate for net annual pine needle yield is 1.38 million tonnes which can support to the energy production in Uttarakhand.

\section{Conflict of interest statement}

Author declares that there is no conflict of interest.

\section{Acknowledgements}

The author is grateful to the Co-Founder of Avani Bio Energy Mr. Rajnish Jain and Mr. Rajendra Kumar Joshi for telephonically sharing the information and sparing their valuable time with me. Author is also thankful to Madam Rashmi Bharti Director of Avani Bio-Energy. Remarkable work done by Avani for developing such ecofriendly technology is highly appreciated and acknowledged.

\section{References}

http://avani-kumaon.org/

\section{How to cite this article:}

Bijalwan, A., 2018. Safe use of highly inflammable dry chirpine (Pinus roxburghii) needles: A successful case study from Pithoragarh District of Uttarakhand, India. Int. J. Curr. Res. Biosci. Plant Biol. 5(5), 56-58. doi: https://doi.org/10.20546/ijcrbp.2018.505.009 